\title{
PROBLEMATIKA KOMPETENSI PEDAGOGI GURU TERHADAP KARAKTERISTIK PESERTA DIDIK
}

\author{
Ilin Nurhamidah ${ }^{1}$ \\ Diterima 8 November 2017, Dipublikasikan 17 April 2018 \\ CPenulis (2018)
}

\begin{abstract}
In the process of education, teachers play an important role as a determinant of the achievement of educational goals. The learning process in the classroom is seen to play an important role when serving learners in learning. Pedagogic competence is the ability to manage the learning of learners which includes students' understanding, design and implementation of learning, evaluation of learning outcomes, and development of participants. Teachers will build a positive attitude in learning, generate curiosity, encourage independence and accuracy of intellectual logic, and create conditions for learning. Therefore, teachers are expected to be able to design activities, communication, and association that leads to learning. Interest, talent, ability, and potential learners will not develop optimally without the help of teachers. Learners one and the other there are basic characteristics, then the teacher must pay attention to individual characteristics of learners. Characteristics of students, ie (a) individuals possessing typical physical and psychical potentials, (b) developing individuals, (c) individuals requiring individual guidance and humane treatment, (d) the individual has the ability to be independent. The problems faced by the teacher about the lack or inability to master the characteristics of learners when implementing the learning, among others: (1) inability to master the characteristics of moral-emotional aspects of learners, (2) lack of mastery of socio-cultural aspects of learners, (3) lack of control (4) lack of mastering the intellectual aspect of the learner, (5) lack of mastering the moral aspect of the learner, (6) there is some kind of child character when learning. Efforts by teachers to integrate values and attitudes education in schools can be done using several approaches, according to Amri (2011: 89) are: (1) cultivation of values, (2) cognitive development, (3) self-clarification, (4) learning do.
\end{abstract}

\section{Keywords}

Teachers, pedagogics, Learners, Characteristics.

\section{PENDAHULUAN}

Guru adalah pendidik. Pendidik merupakan pihak yang membantu anak didik karena ketidakmampuannya sebagai manusia berakal sebagaimana yang dimiliki oleh guru itu sendiri. Guru adalah yang mendidik atau membimbing anak menuju ke arah kedewasaan dalam pelaksanaannya mendidik dalam keluarga maupun dalam suatu lembaga.

Dalam proses pendidikan, guru memiliki peranan yang sangat penting dan sebagai penentu dalam pencapaian tujuan pendidikan. Proses pembelajaran di kelas dipandang dapat memainkan peran penting terutama dalam melayani peserta didik dalam kegiatan belajarnya. Di mana guru akan membangun sikap positif dalam belajar, membangkitkan rasa ingin tahu, mendorong kemandirian dan ketepatan logika intelektual, serta menciptakan kondisi-kondisi

\footnotetext{
$1 \quad$ MTs N 3 Malang

ilinur.hamidah17@yahoo.com
}

Jurnal Teori dan Praksis Pembelajaran IPS Volume 3, No.1, 2018, 27-38 ISSN 2503-5307 
untuk sukses dalam belajar. Oleh karena itu, guru diharapkan mampu merancang kegiatan, komunikasi, dan pergaulan yang mengarah ke pembelajaran.

Selanjutnya Standard Nasional Pendidikan (SNP) Pasal 28 menjelaskan, bahwa yang dimaksud dengan pendidik sebagai agen pembelajaran (learning agent) adalah peran pendidik antara lain sebagai fasilitator, motivator, pemacu, dan pemberi inspirasi belajar bagi peserta didik.

Tugas guru tidak hanya sebagai penyampai informasi kepada peserta didik, tetapi harus menjadi fasilitator yang bertugas memberikan kemudahan belajar kepada peserta didiknya agar mereka dapat belajar dengan suasana yang menyenangkan, gembira, penuh semangat, nyaman, dan berani mengemukakan pendapat secara terbuka. Salah satu hal yang perlu dipahami guru untuk mengefektifkan proses pembelajaran adalah bahwa semua manusia (peserta didik) dilahirkan dengan rasa ingin tahu yang tak pernah terpuaskan, dan mereka semua memiliki potensi untuk memenuhi rasa ingin tahunya.

Mulyasa, (2007) mengemukakan bahwa motivasi adalah tenaga pendorong atau penarik yang menyebabkan adanya tingkah laku ke arah suatu tujuan tertentu. Mulyasa (2007) menegaskan bahwa motivasi dapat menyebab-kan terjadinya suatu perubahan yang ada pada diri manusia, baik yang menyangkut kejiwaan, perasaan, maupun emosi, dan kemudian bertindak atau melakukan sesuatu untuk mencapai tujuan. Motivasi merupakan alah satu faktor yang dapat meningkatkan kualitas pembelajaran, karena peserta didik akan belajar dengan sungguh-sungguh apabila memiliki motivasi yang tinggi. Oleh karena itu, untuk membangkitkan kualitas pembelajaran, guru harus mampu membangkitkan motivasi belajar peserta didik yang diharapkan dapat mencapai tujuan pembelajaran.

Minat, bakat, kemampuan, dan potensi-potensi yang dimiliki oleh peserta didik tidak akan berkembang secara optimal tanpa bantuan guru. Dalam hal ini guru perlu memerhatikan peserta didiknya secara individual, karena antara peserta didik satu dan yang lainnya terdapat karakteristik yang mendasar. Guru harus berpacu dalam pembelajaran dengan memberikan kemudahan belajar bagi seluruh peserta didik, agar dapat mengembangkan potensinya secara optimal. Dalam hal ini guru harus kreatif, profesional, menyenangkan, dan mampu memahami karakteristik peserta didiknya.

Sebagai pemberi inspirasi pelajar, guru harus mampu memerankan diri dan memberikan inspirasi bagi peserta didik, sehingga kegiatan belajar dan pembelajaran dapat membangkitkan berbagai pemikiran, gagasan, dan ide-ide baru. Mulyasa (2007) menambahkan, untuk kepentingan tersebut, guru harus mampu menciptakan lingkungan sekolah yang aman, nyaman dan tertib, optimisme dan harapan yang tinggi dari seluruh warga sekolah, serta kegiatan yang terpusat pada peserta didik (student centered activities), agar dapat memberikan inspirasi, membangkitkan nafsu, gairah, dan semangat belajar. Iklim belajar yang kondusif merupakan tulang punggung dan faktor pendorong yang dapat memberikan daya tarik tersen-diri bagi proses belajar, sebaliknya iklim belajar yang kurang menyenangkan akan menimbul-kan kejenuhan dan rasa bosan.

Peserta didik adalah orang yang belajar. Karakteristik peserta didik adalah keunikan yang dimiliki oleh setiap peserta didik dalam proses belajarnya. Sadulloh (2011) mengatakan peserta didik merupakan seseorang yang sedang berkembang, memiliki potensi tertentu, dan dengan bantuan pendidik ia mengembangkan potensinya tersebut secara optimal. Tirtaraharja (2000) dalam Sadulloh (2011) mengemukakan 4 karakteristik anak didik, yaitu (a) individu yang memiliki potensi fisik dan psikis yang khas, sehingga merupakan makhluk yang unik, (b) 
individu yang sedang berkembang, anak mengalami perubahan dalam dirinya secara wajar, baik ditujukan kepada diri sendiri maupun ke arah penyesuaian dengan lingkungan. Perbedaan perkembangan tersebut harus dipahami oleh pendidik pada tiap fasenya, sehingga atas dasar itu pendidikan dapat mengatur kondisi dan strategi yang relevan dengan kebutuhan peserta didik, (c) individu yang membutuhkan bimbingan individu dan perlakuan manusiawi. Dalam proses perkembangannya anak didik membutuhkan bantuan dan bimbingan, (d) individu yang memiliki kemampuan untuk mandiri. Pada diri anak ada kecenderungan untuk memerdekakan diri, sehingga menimbulkan kewajiban bagi pendidik untuk secara bertahap memberi kebebasan dan pada akhirnya pendidik mengundurkan diri dari usaha memberi bantuan kepada anak, apabila anak-anak benar-benar dipastikan telah mandiri.

Adapun ciri-ciri anak didik Edi Suardi (1984) dalam Sadulloh (2011) mengemukakan, (a) kelemahan dan tidak berdaya, anak dilahirkan dalam keadaan lemah dan tidak berdaya. Adapun keadaan lemah adalah rohani dan jasmaninya. Kelemahan rohani adalah kapabilitas peserta didik membedakan antara yang benar dan salah, sedangkan kelemahan jasmani adalah tidak berdaya peserta didik dalam menahan gangguan cuaca, panas dan dingin. Kelemahan dan tidak berdaya itu dapat berubah menjadi kekuatan dan keberdayaan, yaitu suatu keadaan yang dimiliki oleh orang dewasa, (b) makhluk yang ingin berkembang, keinginan berkembang yang mampu menggantikan ketidakmampuan yang akan membawa mereka ke tingkat kehidupan jasmani dan rohani yang lebih tinggi (c) ingin menjadi diri sendiri. Sadulloh (2010) mengatakan pendidikan yang tidak memperhatikan anak yang ingin menjadi diri sendiri adalah pendidikan bersifat otoriter bahkan memaksa, berarti mematikan pribadi yang sedang tumbuh. Apabila terjadi maka anak akan kehilangan kepribadiannya dan kemudian akan menjadi seorang manusia yang tak punya kemauan, tidak memiliki vitalitas hidup dan tidak punya prakarsa.

Karakteristik fisik Anak didik dalam mencapai dewasa harus melalui perjalanan hidup dalam kurun waktu yang cukup panjang. Perkembangan anak didik mulai bayi, kanak-kanak, anakanak, puber, dan dewasa. Perkembangan fisik mulai banyak perubahan ketika mereka berada pada usia puber. Baik laki-laki maupun perempuan semua akan mengalami perubahan fisik yang urutan kejadian pubertas umumnya sama tiap anak dan waktu terjadinya itu bervariasi, contohnya pertumbuhan tinggi badan, tumbuh bulu halus, pertumbuhan payudara, dan perubahan suara.

Pemahaman terhadap perkembangan peserta didik di atas, sangat diperlukan untuk merancang pembelajaran yang kondusif yang akan dilaksanakan. Rancangan pembelajaran yang kondusif akan mampu meningkatkan motivasi belajar peserta didik sehingga mampu meningkatkan proses dan hasil pembelajaran yang diinginkan.

Karakteristik emosional anak didik salah satu tanda mulai munculnya perkembangan identitas remaja memiliki kecenderungan untuk berpikir tentang apa yang sedang berkecamuk dalam benak mereka sendiri dan mengkaji diri sendiri. Mereka juga mulai menyadari bahwa ada perbedaan antara apa yang mereka pikirkan dan mereka rasakan serta bagaimana mereka berperilaku. Mereka mulai mempertimbangkan kemungkinan-kemungkinan. Remaja mudah dibuat tidak puas oleh diri mereka sendiri. Mereka mengkritik sifat pribadi mereka, membandingkan diri mereka dengan orang lain, dan mencoba untuk mengubah perilaku mereka. Pada remaja usia 18 tahun sampai 22 tahun, umumnya telah mengembangkan suatu status pencapaian identitas. 
Karakteristik intelektual, kemampuan belajar terutama memahami dan menggali materi dan informasi masing-masing peserta didik tentu tidak sama, ada peserta didik yang cepat belajar dan mampu memahami materi ada juga peserta didik yang lambat dan perlu dibimbing secara bertahap dalam belajar.

Kecerdasan bukanlah sesuatu yang bersifat tetap. Ia bagaikan kumpulan kemampuan atau keterampilan yang dapat ditumbuhkembangkan. Kecerdasan adalah kemampuan untuk memecahkan suatu masalah, kemampuan untuk menciptakan masalah baru untuk dipecahkan, dan kemampuan untuk menciptakan sesuatu atau menawarkan suatu pelayanan yang berharga dalam suatu kebudayaan masyarakat.

Jean Piaget mengatakan dia tidak sependapat dengan pandangan yang mengatakan bahwa kecerdasan adalah faktor bawaan, yang berarti manusia tinggal menerima perbedaan-perbedaan yang ada. Pandangan seperti ini dianggap akan membawa pengaruh kurang positif atau bahkan negatif terhadap proses pendidikan dan upaya pengembangan kemampuan berpikir anak.

Kecerdasan ini berkaitan erat dengan genius yaitu: merupakan sifat pembawaan luar biasa yang dimiliki seseorang sehingga ia mampu mengatasi kecerdasan orang-orang biasa dalam bentuk pemikiran dan hasil karya. Kecerdasan ini dapat dibagi ke dalam tiga kelompok besar yakni, 1) IQ (Intelligence Quotient) yang mencakup kecerdasan logis-matematis dan linguistikverbal. 2) EQ (Emotional Quotient) istilah ini dipopulerkan oleh Daniel Goleman (1995) yang mencakup kecerdasan intrapersonal dan interpersonal. Salah satu aspeknya adalah kecerdasan sosial dan pengembangan kepribadian. Di mana seseorang memiliki kemampuan untuk mengerti dan memahami orang lain serta bertindak bijaksana dalam hubungan antar manusia. 3) SQ (Spiritual Quotient) pertama kali digagas oleh Danah Zohar dan Ian Marshall, yang mencakup kecerdasan eksistensial. Umumnya, berkaitan dengan kepercayaan terhadap agama tertentu (terhadap Tuhan dan ciptaan-Nya). Karakteristik kultural peserta didik erat hubungannya dengan kebiasaan belajar dan memperoleh pengetahuan awal.

\section{KOMPETENSI GURU}

Dalam UU Nomor 14 Tahun 2005 tentang Guru dan Dosen, dan diperjelas oleh Permendiknas Nomor 16 Tahun 2007, guru sebagai sebuah profesi harus memiliki empat kompetensi, yaitu kompetensi pedagogi, kepribadian, profesional, dan kompetensi sosial.

1. Kompetensi Pedagogi

Kompetensi ini menyangkut kemampuan seorang guru dalam memahami karakteristik atau kemampuan yang dimiliki oleh murid melalui berbagai cara. Cara yang utama yaitu dengan memahami murid melalui perkembangan kognitif murid, merancang pembelajaran dan pelaksanaan pembelajaran serta evaluasi hasil belajar sekaligus pengembangan murid.

2. Kompetensi Kepribadian

Kompetensi kepribadian ini adalah salah satu kemampuan personal yang harus dimili-ki oleh guru profesional dengan cara mencerminkan kepribadian yang baik pada diri sendiri, bersikap bijaksana serta arif, bersikap dewasa dan berwibawa serta mempunyai akhlak mulia untuk menjadi sauri teladan yang baik. 
3. Kompetensi sosial

Kompetensi sosial adalah salah satu kompetensi yang harus dimiliki oleh seorang pendidik melalui cara yang baik dalam berkomunikasi dengan murid dan seluruh tenaga kependidikan atau juga dengan orang tua/wali peserta didik dan masyarakat sekitar.

4. Kompetensi Profesional

Kompetensi profesional adalah salah satu unsur yang harus dimiliki oleh guru yaitu dengan cara menguasai materi pembelajaran secara luas dan mendalam.

\section{KOMPETENSI PEDAGOGI}

Dalam Standard Nasional Pendidikan penjelasan Pasal 28 ayat (3) butir a dikemukakan bahwa kompetensi pedagogi adalah kemampuan mengelola pembelajaran peserta didik yang meliputi pemahaman peserta didik, perancangan dan pelaksanaan pembelajaran, evaluasi hasil belajar, dan pengembangan peserta didik untuk mengaktualisasikan berbagai potensi yang dimilikinya.

Dalam RPP tentang guru dikemukakan bahwa: kompetensi pedagogi merupakan kemampuan guru dalam pengelolaan pembelajaran peserta didik yang sekurang-kurangnya meliputi hal-hal sebagai berikut, (1) pemahaman wawasan atau landasan pendidikan, (2) pemahaman terhadap peserta didik, (3) pengembangan kurikulum berbasis silabus, (4) perancangan pembelajaran, (5) pelaksanaan pembelajaran yang mendidik dan dialogis, (6) pemanfaatan teknologi pembelajaran, (7) evaluasi hasil belajar, (8) pengembangan peserta didik.

Pedagogi juga merupakan suatu ilmu, sehingga orang menyebutnya ilmu pedagogi. Ilmu pedagogi adalah ilmu yang membicarakan masalah atau persoalan-persoalan dalam pendidikan dan kegiatan-kegiatan mendidik, antara lain seperti tujuan pendidikan, alat pendidikan, cara melaksanakan pendidikan, anak didik, pendidik dan sebagainya. Pedagogi termasuk ilmu yang sifatnya teoritis dan praktis. Oleh karena itu pedagogi banyak berhubungan dengan ilmu-ilmu lain seperti: ilmu sosial, ilmu psikologi, psikologi belajar, metodologi pengajaran, sosiologi, filsafat dan lainnya seperti yang dituangkan oleh Kunandas (2002).

Yunus (2009:8) mengatakan kompetensi pedagogi meliputi, memahami peserta didik secara mendalam, Merancang pembelajaran (termasuk) memahami landasan pendidikan untuk kepentingan pembelajaran), Melaksanakan pembelajaran, Merancang dan melaksanakan evaluasi pembelajaran, dan Mengembangkan peserta didik untuk mengaktualisasikan berbagai potensinya.

Sadulloh (2011:133) mengatakan ada tiga ciri-ciri pendidik antara lain, (1) berwibawa, adanya kewibawaan yang terpancar dari dirinya terhadap peserta didik. Pendidik harus memiliki kewibawaan (kekuasaan batin mendidik) menghindari penggunaan lahir, yaitu kekuasaan yang semata-mata didasarkan kepada unsur wewenang jabatan. Pendidik melalui kewibawaanya mampu membimbing peserta didik ke dalam belajar. Pendidik memiliki sikap untuk mengakui, menerima, meluruskan, memberi pengertian, mengajarkan tanggung jawab dengan penuh keikhlasan dan kasih sayang. (2) mengenal anak didik, karena anak terlahir berbeda maka guru harus mengenal setiap peserta didik secara perorangan, guru dapat melakukannya dengan cara mengakrabkan diri secara personal sehingga akan mengetahui kebutuhan yang dimiliki peserta didik, (3) membantu anak didik, tentulah bantuan yang diberikan guru harus sesuai dengan kebutuhan peserta didik. 
Edi Suardi dalam Sadulloh (2011) mengungkapkan bahwa seorang pendidik harus memenuhi beberapa syarat, yakni (1) harus mengetahui tujuan pendidikan, (2) harus mengenal anak didiknya, (3) harus tahu prinsip dan penggunaan alat pendidikan, (4) harus memiliki sifat bersedia membantu anak didik, (5) harus mampu menyatu dengan anak didiknya, hal itu bukan berarti seorang pendidik sama dengan anak didiknya namun, adanya keterikatan yang menumbuhkan peranan sebagai pendidik yang secara tidak disadari oleh anak didiknya akan mampu mendewasakannya.

Dari lima syarat yang harus dipenuhi guru tersebut jika dipadukan maka dapat disimpulkan guru harus mengetahui karakteristik anak didiknya. Karakteristik peserta didik antara lain, (1) perkembangan fisik, (2) sosio-emosional, (3) moral, (4) kultural, (5) intelektual. Setiap individu pasti mengalami proses pertumbuhan dan perkembangan, karena itu merupakan sifat kodrat manusia yang perlu diperhatikan. Karakteristik yang diperoleh dari pengaruh lingkungan sekitar. Menurut ahli psikologi, kepribadian dibentuk oleh perpaduan faktor pembawaan dan lingkungan. Karakteristik yang bersifat biologis cenderung lebih bersifat tetap, sedangkan karakteristik yang berkaitan dengan faktor psikologis lebih mudah berubah karena dipengaruhi oleh pengalaman dan lingkungan.

\section{DASAR HUKUM KOMPETENSI PEDAGOGI}

Kompetensi pedagogi sesuai dengan UU RI Guru dan Dosen Nomor 14 tahun 2005 dan PP Nomor 19/2005 adalah merupakan kemampuan yang berkenaan dengan pemahaman peserta didik dan mengelola pembelajaran yang mendidik dan dialogis. Tim Direktorat Profesi Pendidikan Ditjen Peningkatan Mutu Pendidikan dan Tenaga Kependidikan (2006) telah merumuskan secara substantif kompetensi pedagogi yang mencakup kemampuan terhadap peserta didik. Pemahaman wawasan atau landasan kependidikan pengembangan peserta didik untuk mengaktualisasikan berbagai potensi yang dimilikinya.

Menurut Undang-undang Sistem Pendidikan Nasional (SISDIKNAS) Nomor 20 Tahun 2003, pasal 1 ayat 1 berisi pengertian pendidikan adalah "Usaha sadar dan terencana untuk mewujudkan suasana belajar dan proses pembelajaran agar peserta didik secara aktif mengembangkan potensi dirinya untuk memiliki kekuatan spiritual keagamaan, pengendalian diri, kepribadian, kecerdasan akhlak mulia serta keterampilan yang diperlukan dirinya, masyarakat, bangsa dan negara”. Dari itu kita dapat mengambil makna dari pendidikan yakni menciptakan warga negara yang bertaqwa, berakhlak, dan terampil. Untuk mencapai tujuan tersebut maka diselenggarakan serangkaian kegiatan pembelajaran yang bersifat formal, non formal, maupun informal dengan berbagai jenjang mulai dari pendidikan usia dini hingga pendidikan tinggi.

Dari berbagai pengertian di atas itu dapat diketahui bahwa kompetensi pedagogi itu adalah kemampuan pemahaman tentang peserta didik secara mendalam dan penyelenggaraan pembelajaran yang mendidik pemahaman tentang peserta didik meliputi pemahaman tentang psikologi perkembangan anak, sedangkan pembelajaran yang mendidik meliputi kemampuan merancang pembelajaran, mengimplementasikan pembelajaran, menilai proses hasil pembelajaran, dan melakukan perbaikan secara berkelanjutan.

Dalam Peraturan Menteri Pendidikan Nasional Nomor 16 tahun 2007 telah ditetapkan standar kompetensi pedagogi guru. Standar kompetensi pedagogi guru merupakan kemampuan minimal yang harus dimiliki guru dalam menyelenggarakan pembelajaran. Standar kompetensi guru mencakup kompetensi inti guru yang dijabarkan ke dalam kompetensi guru. Berikut ini 
disajikan standar kompetensi pedagogi guru mata pelajaran di SD/MI, SMP/MTs, SMA/MA, dan SMK/MAK:

\begin{tabular}{|c|c|c|}
\hline No & $\begin{array}{c}\text { KOMPETENSI INTI } \\
\text { GURU }\end{array}$ & KOMPETENSI GURU MATA PELAJARAN \\
\hline 1. & $\begin{array}{l}\text { Menguasai karakteristik } \\
\text { peserta didik dari aspek } \\
\text { fisik, moral, spiritual, } \\
\text { sosial, kultural, } \\
\text { emosional, dan } \\
\text { intelektual. }\end{array}$ & $\begin{array}{l}\text { 1.1. Memahami karakteristik peserta didik yang berkaitan } \\
\text { dengan aspek fisik, intelektual, sosial-emosional, } \\
\text { moral, spiritual, dan latar belakang sosial-budaya. } \\
\text { 1.2. Mengidentifikasi potensi peserta didik dalam } \\
\text { mata pelajaran yang diampu. } \\
\text { 1.3. Mengidentifikasi bekal-ajar awal peserta didik } \\
\text { dalam mata pelajaran yang diampu. }\end{array}$ \\
\hline
\end{tabular}

Gambar 1. Standar Kompetensi Guru Mata Pelajaran di SD/MI, SMP/MTs, SMA/MA, dan SMK/MAK

\section{PROBLEMA GURU TERHADAP KARAKTERISTIK PESERTA DIDIK}

Beberapa guru bahasa yang saya wawancara menyampaikan permasalahan tentang kurang atau ketidakmampuannya menguasai karakteristik peserta didik yang dihadapi ketika melaksanakan pembelajaran, di antaranya:

1. Kurangnya kemampuan dalam menguasai karakteristik peserta didik dari aspek moralemosional, contohnya peserta didik pada usia remaja dalam hal ini adalah peserta didik MTs baik negeri maupun swasta, ketika pembelajaran peserta didik wanita sering tidak menghiraukan guru mereka asyik bercermin dalam kelas, izin ke belakang hanya untuk membenahi penampilan (jilbab), suka ramai sendiri membicarakan lawan jenis (pacar) dan kebiasaa sehari-hari, terlebih jika di MTs gaya berdandan peserta didik putri yang berlebihan dengan menggunakan eyeliner, lip-gloss, softlense, kutek, model jilbab modern yang tentu hal itu akan mengganggu proses pembelajaran bagi peserta didik sendiri dan juga yang lain. Peserta didik sudah mulai enggan dinasihati, sudah tidak takut dengan tata tertib dan hukuman.

Ada beberapa masalah yang kerap muncul ketika pembelajaran berlangsung, peserta didik ada yang melamun, ada yang juga tiba-tiba marah tanpa sebab, emosinya meletup-letup, terkadang ada juga yang suka pukul meja atau temannya sendiri, padahal sikap tersebut ia lakukan dengan sadar dan ia tahu hal tersebut salah.

Setelah diamati beberapa peserta didik yang memiliki karakteristik tersebut, ia merasa jengkel, tidak puas, putus asa, kesal tugas dari guru tidak terselesaikan karena materi yang dijelaskan kurang dimengerti, adanya masalah dalam keluarga, dan masalah dalam hubungan pertemanan mereka.

2. Kurangnya menguasai karakteristik peserta didik dari aspek sosio-kultural.

Peserta didik berasal dari latar belakang keluarga dengan lingkungan yang berbeda-beda. Dalam kompetensi anggota tubuh peserta didik ada yang mengaktualisasikan berbeda dengan materi tentunya ini dapat mengacaukan suasana pembelajaran yang kondusif menjadi tidak kondusif. Sesuatu yang biasa pada umumnya dapat menjadi tabu jika peserta didik berbeda cara mengaktualisasikannya. Terlebih jika pembiasaan menggunakan bahasa yang santun juga masih minim, maka hal yang timbul ketika proses pembelajaran pendidik merasa kurang disegani atau dihormati oleh peserta didiknya. 
3. Kurangnya menguasai karakteristik peserta didik dari aspek fisik. Setiap peserta didik memang terlahir berbeda dan memiliki keunikan. Tidak berbeda peserta didik baik yang di sekolah negeri maupun swasta mereka memiliki kelebihan dan kekurangan secara fisik. Hal tersebut membawa problem tersendiri bagi tiap peserta didik dan pendidiknya, di antaranya (1) perbedaan tinggi badan baik laki-laki maupun perempuan, ini berpengaruh pada letak atau denah tempat duduk yang mana peserta didik putri tidak boleh duduk bersanding dengan peserta didik putra, kemudian peserta didik yang tinggi mengalami masalah pendengaran atau penglihatan jika ada di posisi belakang. (2) Perbedaan jenis kulit, kecantikan dan ketampanan yang dimiliki akan berdampak pada rasa percaya diri yang tinggi dampaknya anak didik seperti ini sering menjadi pusat perhatian bagi peserta didik yang lain, terkadang karena banyak yang mengelu-elukan anak didik seperti ini cenderung congkak tidak menghargai guru yang berpenampilan sangat sederhana, (3) keterbatasan jarak pandang atau penglihatan, (4) kualitas volume suara, hal ini akan terasa ketika pengajar bahasa mengajarkan keterampilan berbicara, volume peserta didik yang cenderung pelan kurang mampu memaksimalkan keterampilan berbicaranya. (5) Ciri-ciri fisik yang mulai menonjol di usia pubertas. Terlebih peserta didik putri akan merasakan krisis percaya diri karena munculnya jerawat dan beberapa ciri fisik yang menunjukkan gejala pubertas.

4. Kurangnya menguasai karakteristik peserta didik dari aspek intelektual. Anak yang pandai, pintar, atau memiliki intelektual yang tinggi cenderung bersikap diam, pasif, namun dalam kelas tersebut juga terdapat peserta didik yang memiliki tingkat intelektual yang tidak begitu tinggi atau bahkan rendah, mereka cenderung aktif, sebagai pengecoh, pengacau, kunci kurang lancarnya jalannya pembelajaran, dan tidak menyelesaikan tanggung jawabnya yakni menuntaskan PR. Terkadang peserta didik yang lamban menerima materi atau ilmu tentang kompetensi yang harus dicapai ada yang bersifat diam dan pasif namun enggan menyampaikan kurangnya pemahaman terhadap materi yang disampaikan guru sehingga pada tahap evaluasi hasil pembelajaran dalam kurun waktu semester masih muncul kondisi tidak tuntas pada sebagian peserta didik yang memiliki tingkat intelektual yang rendah.

5. Kurangnya minat baca bagi peserta didik ternyata berdampak pada tingkat intelektualitas peserta didik. Dalam kurikulum 2013 ini pembelajaran berpusat pada peserta didik, namun jika pengetahuan peserta didik sangat minim, maka pembelajaran akan kembali berpusat pada guru yang seharusnya sebagai fasilitator kembali sebagai centre.

Contoh yang terjadi di lapangan, seorang guru selalu berusaha menstimulus peserta didiknya, namun peserta didik tidak mampu meresponsnya.

Berbeda dari beberapa contoh di atas mengenai karakteristik intelektual peserta didik, di kelas percepatan atau akselerasi atau saat ini mengganti namanya dengan PDCI yakni peserta didik yang memiliki kecerdasan istimewa. Guru sering menjumpai anak lebih acuh terhadap lingkungan belajarnya, terlihat lebih sombong dan tidak menghargai keberadaan guru. Beberapa terjadi dalam suatu kelas, pernah dijumpai mereka hanya ingin menghabiskan kebosanan karena guru monoton dengan melakukan permainan yang membahayakan fisik dan psikologinya yaitu permainan hipnotis dan saling pegang alat kelamin temannya.

6. Kurangnya menguasai karakteristik peserta didik dari aspek moral. Ketika guru menjelaskan materi, sering dirasa kurang menghargai. Mereka sering terlihat ramai sendiri, cuek, bahkan ada yang tertidur. Hal ini mungkin pola atau cara belajar dari generasi $\mathrm{Z}$ yang sudah melek teknologi sehingga merasa mampu mencari informasi di internet (Purnomo, 
dkk. 2016). Entah karena cara mengajar guru yang kurang menarik atau mata pelajaran yang membosankan. Guru sudah berupaya semaksimal mungkin untuk bisa menguasai keadaan kelas pada saat proses pembelajaran dan meskipun guru juga memberikan treatmen goal akhir sukses UN peserta didik masih belum ada peningkatan ke arah positif.

Dalam proses pembelajaran yang saya temukan ada beberapa jenis karakter anak, ada yang berkarakter positif dan berkarakter negatif. Karakter positif di antaranya toleran yang mudah menerima orang lain sebagai sahabatnya, kecenderungan menguasai temantemannya, kecenderungan bermotivasi untuk berprestasi, lugas, tegas, dan tidak banyak bicara, dan tipe anak petualang yang menyukai hal-hal yang baru. Namun ada anak yang memilik karakter yang dominan negatif di antaranya nakal yang selalu membuat ulah, tidak teratur yang memiliki kecenderungan tidak teliti, provokator yang cenderung suka mencari gara-gara dan mendapat perhatian dari orang lain. Anak yang memiliki karakter penguasa biasanya suka mengintimidasi temannya, mengancam, menyudutkan, dan ia menginginkan orang lain tunduk dan patuh pada perintahnya. Dan tipe pembangkang yang malah bangga jika ia mempunyai perbedaan dengan temannya, ia lebih percaya diri dengan tampil beda anak tipe ini sering tidak melaksanakan tata tertib contohnya seragam tidak lengkap atau dengan mengenakan atribut yang salah atau jadwal pelajaran Bahasa Indonesia buku yang dibawa Bahasa Inggris, dan banyak lagi.

Dari beberapa karakter peserta didik baik negatif dan positif yang ada dalam proses pembelajaran tentu akan mengganggu jalannya pembelajaran dan hal itu sangat merugikan guru karena program tidak dapat berjalan lancar dan bagi peserta didik yang berkarakter positif akan berdampak pada penangkapan makna dari kejadian-kejadian yang tidak menyenangkan.

\section{SOLUSI PROBLEMATIKA PENGUASAAN KARAKTERISTIK PESERTA DIDIK}

Perbincangan mengenai pendidikan karakter sudah marak di berbagai institusi atau lembaga pendidikan. Karakter yang dibangun pada peserta didik tidak semata-mata tugas guru atau sekolah. Mengingat mereka dalam beraktivitas tidak hanya di sekolah, melainkan di rumah dan sekaligus sebagai bagian dari masyarakat luas. Di satu sisi guru dituntut mendidik peserta didik menjadi generasi muda yang berkarakter baik, namun di sisi yang berbeda anak melihat orang tua di rumah yang sering kali berbuat tidak taat pada peraturan dan tidak menghargai orang lain.

Pendidikan karakter menjadi bagian dari proses pembentukan akhlak anak bangsa yang diharapkan mampu menjadi fondasi utama dalam meningkatkan derajat dan martabat bangsa Indonesia. Amri (2011) mengatakan bahwa pembentukan karakter itu dimulai dari fitrah yang diberikan Tuhan yang kemudian membentuk jati diri dan perilaku. Dalam prosesnya sendiri fitrah yang alamiah ini sangat dipengaruhi oleh keadaan lingkungan sehingga lingkungan memiliki peranan yang cukup besar dalam membentuk jati diri dan perilaku.

Kebutuhan akan penanaman pendidikan karakter dirasa penting setelah maraknya bentuk penyimpangan moral, intelektual, sosial, dan emosional peserta didik. Tentu hal ini akan mencemaskan para orang tua dan terlebih guru karena tidak mampu mendidik anak didiknya menjadi manusia dewasa yang dicita-citakan oleh pendidikan nasional yakni menjadi warga negara yang bertaqwa, berakhlak mulia, dan terampil.

Pada masa Kurikulum KTSP membuktikan bahwa desain pendidikan sangat tidak seimbang karena hanya menonjolkan pencapaian aspek intelektual atau ranah kognitif semata dan 
mengabaikan aspek penanaman nilai atau sikap yang diduga kuat dapat menyebabkan munculnya degradasi pada anak sekolah. Gaffar dalam Amri (2011) menyebutkan bahwa pendidikan bukan hanya sekedar menumbuhkan dan mengembangkan keseluruhan aspek kemanusiaan tanpa diikat oleh nilai, tetapi nilai itu merupakan pengikat dan pengarah proses pertumbuhan dan perkembangan tersebut.

Nilai atau sikap dapat menuntun setiap individu menjalankan tugas-tugasnya, seperti nilai kejujuran, nilai kesederhanaan, nilai penghargaan, nilai keingintahuan, dan sebagainya. Amri, (2011) menambahkan bahwa pendidikan nilai ialah upaya mewujudkan manusia seutuhnya yaitu manusia yang beriman dan bertaqwa kepada Tuhan Yang Maha Esa, berakhlak mulia, manusiawi, dan peduli terhadap kebutuhan serta kepentingan orang lain; yang intinya menjadi manusia yang terdidik baik terdidik dalam imannya, ilmunya maupun akhlaknya serta menjadi warga negara dan dunia yang baik.

Upaya yang dapat dilakukan guru untuk mengintegrasikan pendidikan nilai dan sikap di sekolah dapat dilakukan dengan menggunakan beberapa pendekatan, menurut Amri (2011) ialah :

1. Penanaman nilai ialah suatu pendekatan yang menitikberatkan pada penanaman nilai-nilai sosial agar mampu terinternalisasi dalam diri peserta didik dengan tujuan peserta didik dapat menerima nilai atau norma sosial, nilai yang tidak sesuai dengan tuntutan lingkungan dan kebutuhan peserta didik dapat diubah sehingga sesuai dengan nilai-nilai sosial yang diinginkan. Guru dapat menerapkannya dalam proses pembelajaran di antaranya dengan penanaman nilai keteladanan, penguatan sikap positif dan negatif, simulasi, bermain peran, tindakan sosial, dan lainnya.

2. Perkembangan kognitif

Peserta didik merupakan individu yang memiliki potensi kognitif yang terus tumbuh dan berkembang. Melalu pendekatan ini guru dapat memotivasi peserta didik untuk membiasakan berpikir aktif tentang masalah-masalah moral yang ada di sekitar mereka, di mana peserta didik di latih membuat keputusan-keputusan moral. Sehingga pada waktunya nanti anak dituntut mempertanggungjawabkan apa yang telah diputuskannya. Pendekatan ini bertujuan agar peserta didik mampu membuat keputusan moral mulai dari yang sederhana hingga yang kompleks berdasarkan tata nilai yang tinggi.

3. Klarifikasi diri

Pendekatan ini menekankan untuk membantu peserta didik mengkaji perasaan dan perbuatannya sendiri, kemudian secara bertahap kemampuan kesadaran mereka ditingkatkan terhadap nilai-nilai mereka sendiri.

Pendekatan ini bertujuan membantu peserta didik untuk menggali, menemukan, menyadari serta mengidentifikasi nilai-nilai yang terdapat pada diri mereka sendiri serta nilai-nilai orang lain. Kedua, mendorong peserta didik untuk mampu berkomunikasi secara terbuka dan jujur dengan orang lain yang berkaitan dengan nilai-nilai yang mereka miliki, ketiga memfasilitasi peserta didik meningkatkan kemampuan berpikir rasional dengan disertai kesadaran emosional dalam memahami hal-hal yang berhubungan dengan perasaan, nilainilai dan pola tingkah laku mereka sendiri.

4. Pembelajaran berbuat

Pendekatan ini menekankan pada usaha guru untuk memfasilitasi peserta didik untuk melakukan perbuatan-perbuatan moral dengan tujuan membantu peserta didik melihat diri mereka sebagai makhluk individu dan makhluk sosial dalam interaksi sehari-hari di tengah 
kehidupan bermasyarakat. Artinya mereka adalah sosok individu yang utuh yang memiliki hak dan kewajiban yang harus dilaksanakan dengan penuh tanggung jawab dengan demikian mereka akan merasa kebebasan yang mereka miliki adalah kebebasan yang dibatasi oleh hak orang lain.

RPP adalah salah satu upaya guru dalam mengoptimalkan pembelajaran yang di dalamnya terdapat program, sasaran, dan paparan tentang hal apa saja yang harus dilaksana-kan oleh seorang guru kepada peserta didiknya. Dalam tatap muka tersebut guru dapat menghimbau perilaku berkarakter dan guru juga sebagai panutan bagi mereka hendaknya mampu dijadikan teladan yang baik. Untuk itu seorang guru harus mampu menunjukkan sikap berkarakter yang diharapkan.

Menurut Permendikbud nomor 103 tahun 2014 tentang pedoman pelaksanaan pembelajaran bahwa dalam KI, Kd, indikator pencapaian beserta tujuan pembelajarannya sangat ditekankan pada penanaman karakter pada diri peserta didik. Guru sebagai fasilitator diharapkan guru dapat membimbing sikap dan tutur kata peserta didik sebagai manusia dewasa yang berkarakter. Dalam RPP tersebut juga terdapat lima pendekatan dalam proses pembelajaran yaitu menstimulus/merangsang melalui kegiatan mengamati, menanya sebagai upaya umpan balik tentang apa yang diamati oleh peserta didik, dilanjutkan dengan mengumpulkan data sebagai upaya menggali pengetahuan peserta didik mengenai kompetensi yang diajarkan, anak juga diminta untuk menyampaikan apa yang mereka dapatkan selama proses pembelajaran yakni pada mengasosiasi, dan tahap akhir adalah menyimpulkan apa yang mereka dapatkan atau hal baru apa yang mereka temukan. Kemudian dilengkapi dengan tiga ranah penilaian di antaranya afektif, kognitif, dan psikomotorik yang dapat memacu dan mengendalikan kreativitas gerak dan tingkah laku peserta didik.

Bimbingan Konseling (BK) merupakan salah satu komponen sekolah/madrasah yang memiliki tujuan membentuk pribadi peserta didik secara optimal. BK memiliki fungsi pemahaman, pencegahan, pengentasan, dan pemeliharaan dan pengembangan dengan beberapa tujuan yakni menemukan pribadi, mengenal lingkungan, dan merencanakan masa depan. BK dalam sistem kerjanya selalu mengaitkan lingkungan keberadaan peserta didik dengan masalah yang sedang dihadapinya dengan harapan individu tersebut akan memiliki pribadi yang mandiri. Bidang bimbingan BK sendiri di antaranya pribadi, sosial, belajar, dan karier. beberapa asas yang dimiliki BK adalah kerahasiaan, kesukarelaan, dan keterbukaan. Dari beberapa hal tersebut dapat kita simpulkan BK mampu sebagai penyemai benih-benih karakter bagi peserta didik di lingkungan sekolah/madrasah.

Dalam situasi pembelajaran di kelas guru hendaknya berperan seperti BK kepada peserta didiknya, dengan memahami pribadi dan lingkungan peserta didik, sebaiknya guru merencanakan dan menyelenggarakan proses pembelajaran sesuai karakteristik peserta didiknya dengan penuh keikhlasan dan tanggung jawab. Guru dalam peranannya sebagai pendidik harus memahami kelemahan yang dimiliki oleh tiap-tiap anak didiknya. Karena pendidik tidak semata sebagai tenaga profesional yang memiliki peranan sebagai sumber ilmu pengetahuan namun juga sebagai mata rantai keberhasilan pendidikan bagi peserta didik yang kelak akan tumbuh sebagai manusia dewasa yang dapat memberikan peranannya dalam masyarakat dan lingkungan. 
Pendidikan karakter juga tidak bisa diserap melalui sekedar ceramah atau tulisan-tulisan slogan saja, akan tetapi harus dilakukan dan harus berulang. Guru tidak dapat hanya sekedar menyampaikan butir-butir tata tertib atau hanya sekedar membacakan dalil dan hadist, guru hendaknya bersikap dengan melakukannya terlebih dahulu, yakni sebagai teladan atau contoh bagi peserta didiknya.

Tidak ada masalah yang tidak ada jalan keluarnya. Dengan segala kompetensi yang melekat pada seseorang yang berprofesi sebagai guru. Guru dapat melakukan sharing, saling berbagi dan berkeluh kesah dengan teman sejawat, atasan, atau orang tua peserta didik. Perlunya pihak lain sebagai pembicara terkait permasalahan yang sedang dihadapi oleh pendidik tersebut tentunya dengan materi mendidik kepada peserta didik dengan harapan akan meningkatnya kualitas emosional mereka sehingga peserta didik mampu mengendalikan peserta didik yang menyukseskan proses pembelajaran.

\section{SIMPULAN}

Guru akan membangun sikap positif dalam belajar, membangkitkan rasa ingin tahu, mendorong kemandirian dan ketepatan logika intelektual, serta menciptakan kondisi untuk dapat belajar. Oleh karena itu, guru diharapkan mampu merancang kegiatan, komunikasi, dan pergaulan yang mengarah ke pembelajaran. Minat, bakat, kemampuan, dan potensi peserta didik tidak akan berkembang secara optimal tanpa bantuan guru. Peserta didik satu dan yang lainnya terdapat karakteristik yang mendasar, maka guru harus memerhatikan secara individu karakteristik peserta didiknya. Permasalahan yang dihadapi guru tentang kurang menguasai karakteristik peserta didik ketika melaksanakan pembelajaran, di antaranya: (1) ketidakmapuan dalam menguasai karakteristik aspek moral-emosional peserta didik, (2) kurangnya penguasaan aspek sosio-kultural peserta didik, (3) kurangnya menguasai aspek fisik peserta didik, (4) kurangnya menguasai aspek intelektual peserta didik, (5) kurangnya menguasai aspek moral peserta didik, (6) terdapat beberapa jenis karakter anak ketika pembelajaran.

\section{DAFTAR PUSTAKA}

Amri, Sofan. (2011). Implementasi Pendidikan Karakter dalam Pembelajaran. Jakarta: Prestasi Pustaka

Iskandarwassid, (2008). Strategi Pembelajaran Bahasa. Bandung: Remaja Rosdakarya Kunandas, (2002). Profesional Implementasi KTSP. Jakarta: Jakarta: Rineka Cipta

Muhammad Asyam Farrosi. (2012). Perkembangan Sosio-Emosional Peserta Didik http://asyamforex.blogspot.co.id/2012/11/perkembangan-sosio-emosional-peserta.html: online. 15 Maret 2016

Mulyasa, (2007). Standart Kompetensi dan Sertifikasi Guru. Bandung: Remaja Rosdakarya

Purnomo, A., Ratnawati, N. and Aristin, N.F., 2016. Pengembangan Pembelajaran Blended Learning Pada Generasi Z. Jurnal Teori dan Praksis Pembelajaran IPS, 1(1), pp.70-76.

Sabri, Alisuf. (1998). Ilmu Pendidikan. Jakarta: Pedoman Ilmu Jaya

Sadulloh, Uyoh. (2011). Pedagogi (Ilmu Mendidik). Bandung: Alfabeta

Undang-undang No.14 Tahun 2005 Tentang Guru dan Dosen. Online: 24 Maret 2016. http://sindikker.dikti.go.id/dok/UU/UUNo142005\%28Guru\%20\&\%20Dosen\%29.pdf

Yunus, Abu Bakar. (2009). Profesi Keguruan. Surabaya: IAIN Sunan Ampel 